\title{
SIMILARITY RELATIONSHIPS AMONG GREEK MIDDLE MIOCENE TO EARLY - MIDDLE PLEISTOCENE MAMMAL ASSEMBLAGES
}

\author{
Kostopoulos D. S. ${ }^{1}$, and Koufos G. D. ${ }^{1}$ \\ ${ }^{1}$ Aristotle University of Thessaloniki, Faculty of Geology, Laboratory of Geology \& Paleontology, \\ dkostop@geo.auth.gr,koufos@geo.auth.gr
}

\begin{abstract}
The Greek fossil record of small and large mammal Local Faunal Assemblages is studied and compared by means of cluster analysis techniques using Jaccard similarity index and unweighted pair-group method. The analysis allow recognizing a good arrangement of the Greek LFAs according to time and a main cluster gap, corresponding to an important faunal renewal that, however, is not synchronous in the large and small mammal community. Minor groupings of large mammal faunas seem also to fit with main climatic trends, whereas the small mammal assemblage appears to undergo longer periods of taxonomic stability.
\end{abstract}

Key words: Mammal Faunas, Greece, Biochronology, Neogene-Quaternary.

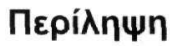

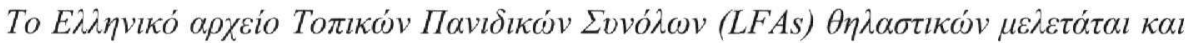

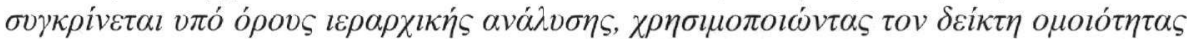

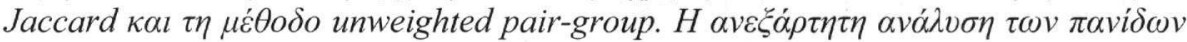

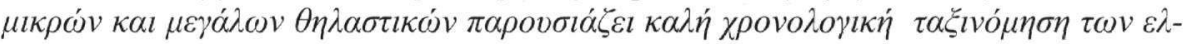

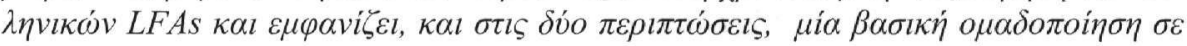

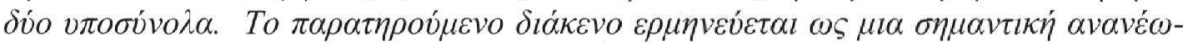

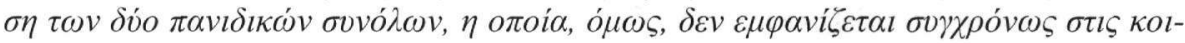

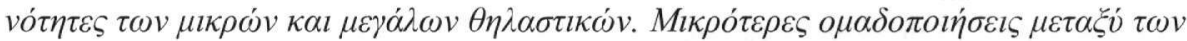

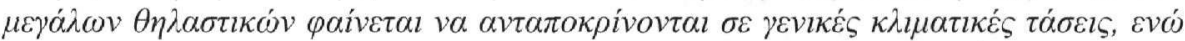

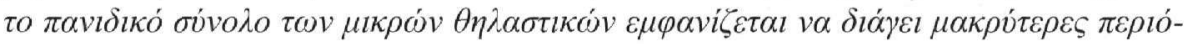

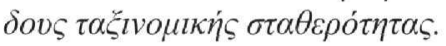

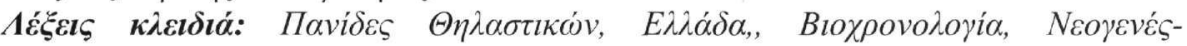

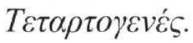

\section{Introduction}

The Greek Neogene/Quaternary continental record exhibits an important archive of fossil mammal assemblages spanning in time from the middle Miocene up to the late Pleistocene. In the absence of any particular (i.e., local) biochronological/biostratigraphical scheme, both large and small mammal faunas from Greece are usually referred to the well established West European scales, such as the European Mammal Neogene System (MN) of Mein $(1975,1990)$ and its Quaternary supplements by Guerin $(1982,1990)$, the Italian Faunal Units (FU) of Gliozzi et al. (1997) or the Spanish succession of biozones and continental stages (Agusti et al. 2001). Nevertheless, there is 
no work till now analyzing the entire Greek biochronological succession of either large or small mammal faunas neither their possible interrelationships.

As each Local Faunal Assemblage (LFA) is a partial record of a particular homogeneous fauna, lived during a definite time span (otherwise of a biochronological unit), multivariate techniques have been proved an efficient tool in the quantification of similarities among LFAs, which could consequently allow the recognition of sequences of non-overlapping and ecologically adjusted assemblages of taxa, living together in a given time and space (Alberdi et al. 1997, Azanza et al. 2003, Palombo et al. 2003, 2006 and literature therein). And in vice versa, discontinuities between these "zones" of taxonomical homogeneity might reflect faunal reconstructions through time droved by environmental changes, or structural changes droved by geographical barriers.

The basic aim of this work is to analyse the Greek middle Miocene to early-middle Pleistocene faunal successions of both the large and small mammal assemblages and to contrast their patterns either with the established biochronological schemes, as well as between them with respect to ecological and geographical factors.

\section{Materials and Methods}

The most important Greek fossil mammalian taxa-gatherings, representing Local Faunal Assemblages (LFAs) of middle Miocene (MN4) to early-middle Pleistocene (MNQ20/21) age have been chosen. Excluding mammal assemblages with less than 3 taxa identified at species level, the case study finally includes 53 large-mammal LFAs and 46 small-mammal LFAs. As a total 99 LFAs were analyzed. The faunal lists used in the analysis are published by Bonis \& Koufos (1999), Koufos \& Kostopoulos (1997), and Koufos $(2001,2006)$ with up-to-date records, personal observations and critical reviews. In order to standardize the taxonomy and to increase the taxonomical confidence, forms originally identified as "conformis" and "affinis" were included within the nominated taxon. Uncertain taxonomical forms (e.g., Bovidae indet., ?Mimomys etc. ) were excluded, whereas forms referred to as "sp." were measured as distinct species. 232 species of large mammals and 230 species of small mammals were considered in the analysis. The initial localityby-taxa datasets are compiled in two "presence/absence" matrices: one for the large and another one for the small mammals. The presence of a taxon in a LFA was coded " 1 ". Both matrices are available on request.

Following previous works (Alberdi et al. 1997, Azanza et al. 2003, Palombo and Valli, 2004, 2005, Palombo et al. 2006) we evaluated similarities among LFAs on the basis of Jaccard binary coefficient (Shi, 1993), performing cluster analysis at species level using unweighted pair-group (UPGMA) method (PAST statistical package, Hammer et al. 2001, Hammer \& Harper 2006).

\section{Results}

\subsection{Similarities among large mammal LFAs}

The Q-mode dendrogram resulting from the clustering of similarities at species level (Fig. 1) divides the large mammal faunas in two main groups, leaving the earliest (early MN4) and poorly known assemblage of Aliveri distantly related to them. The main split reveals a major separation between the middle Miocene to early Pliocene LFAs (Cluster A) from the one hand and the middle Pliocene to early-middle Pleistocene LFAs (Cluster B) from the other. Thus, it appears that the most important break in the faunal composition of the large mammal community occurs at the beginning of Pliocene and not at the Mio-Pliocene boundary, as it would be expected.

The first cluster A includes two main subclusters A1 and A2, from which A2 is further divided in two groups A2.1 and A2.2 (Fig. 1). A1 is weakly related to the rest of Cluster A and groups together Thymiana B (MN5) and Antonios (MN4/5) on the basis of the common presence of Sanitherium slangintweiti and Dorcatherium peneckei. In any case, the serious gap of MN5 to MN9 
large mammal faunas certainly obscures the results. Apart from the scanty large mammal assemblage of Kastellios (MN9), A2 groups together the LFAs of late Miocene (A2.1) and early Pliocene (A2.2) age. The latest Miocene (late MN13) LFA of Maramena already shows a separation from the main late Miocene subcluster (A2.1) probably indicating a transitional condition toward A2.2, which is characterized by the association Sus minor + Hipparion ex. gr. longipes or crassum.

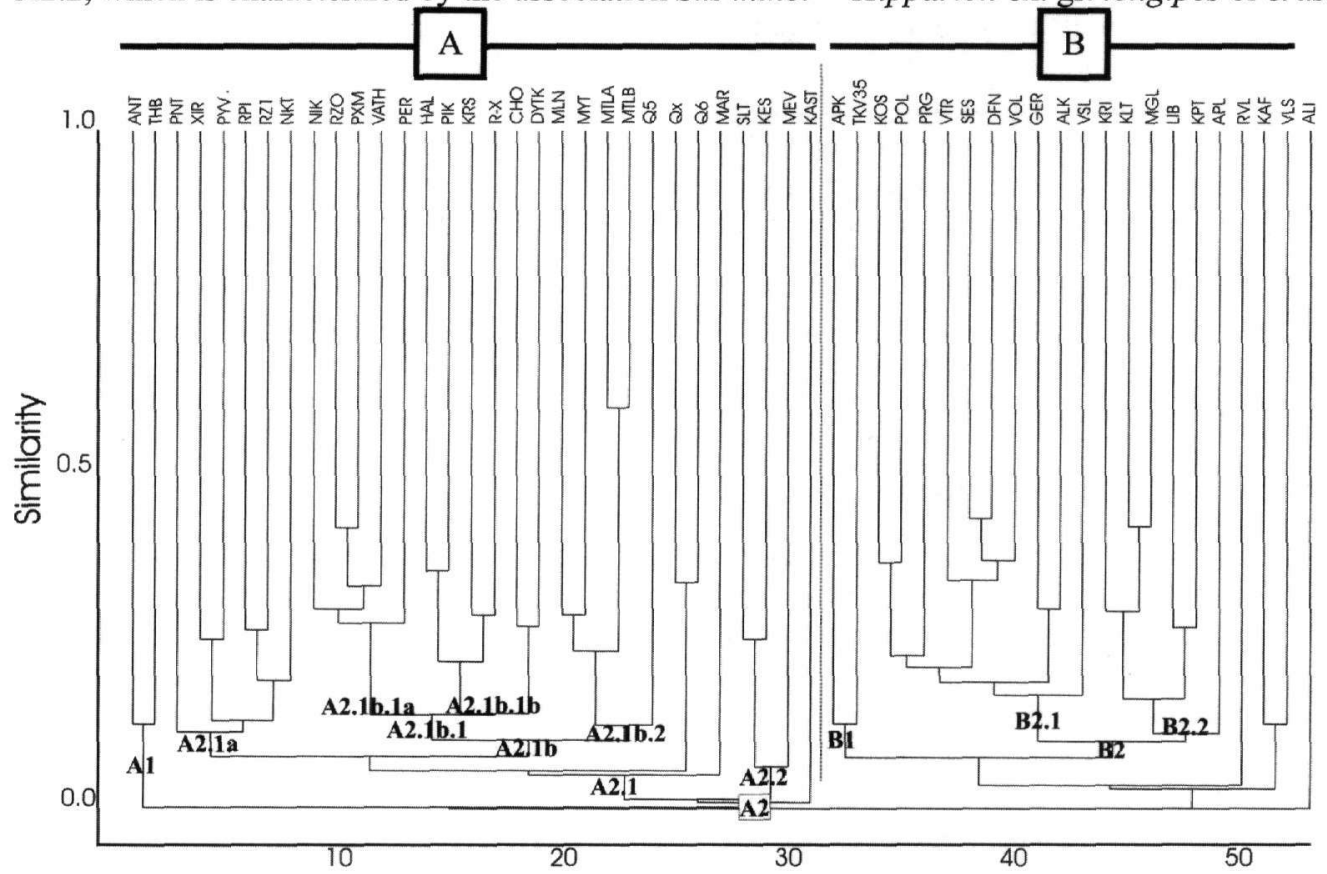

Figure 1 - Q mode dendrogram of 53 Greek large mammal faunas (LFAs). Cophenetic correlation: 0.89

Abbreviations: Aliveri (ALI); Antonios (ANT); Thymiana B (THB); Pentalophos (PNT); Xirochori (XIR); Pyrgos Vassilisis (PYV); Ravin de la Pluie (RPl); Ravin des Zouaves 1 (RZ1); Nikiti-1 (NKT); Nikiti-2 (NIK); Ravin des Zouaves 5 (RZO); Prochoma (PXM); Vathylakkos 1, 2, 3 (VATH); Perivolaki (PER); Halmyropotamos (HAL); Pikermi (PIK);

Kerassia (KRS); Ravin X (RX); Chomateres (CHO); Dytiko 1, 2, 3 (DYTK); Mytilinii 4-Samos (MLN); Mytilinii 3-Samos (MYT); Mytilinii 1A (MTLA); Mytilinii 1B (MTLB); Quarry 5-Samos (Q5); Quarry X-Samos (Qx); Quarry 6-Samos (Q6); Maramena (MAR); Silata (SLT); Kessani 1,2 (KES); Megalo Emvolo (MEV); Kastelios-Crete (KAST); Apolakkia (APK); Tourkovounia 3-5 (TKV35); Kos Island (KOS); Polylakkos (POL); Pyrgos (PRG); Vatera (VTR); Sesklo (SES); Dafnero (DFN); Volakas (VOL); Gerakarou (GER); Alikes (ALK); Vassiloudi (VSL); Krimni (KRI): Kalamoto (KLT);

Megalopolis (MGL); Libakos (LIB); Kapetanios (KPT); Apollonia (APL); Ravine of Voulgarakis (RVL); Kaiafas (KAF); Volos (VLS)

A2.1 is further divided in two prime subclusters A2.1a and A2.1b with clear chronological meaning. A2.1a gathers late Vallesian (MN9/10, MN10) LFAs with typical faunal association Ouranopithecus macedoniensis + Hipparion macedonicum + Samotragus praecursor, whereas A2.1b subcluster unites Turolian faunas (MN11-13). Inside A2.1b there are also two groups of LFAs. The first one A2.1b.1 includes the MN11-13 LFAs of continental Greece, further segregated chronologically into two subclusters, A2.1b.1a grouping only MN11 assemblages (Adcrocuta eximia + Plioviverops obrigni + Hipparion dietrichi + Gazella pilgrimi + Nisidorcas planicornis + Tragoportax rugosifrons) and A2.1b.1b grouping the MN12-13 assemblages (Ceratotherium neumayri + Hipparion mediterraneum + Pliocervus pentelicus + Tragoportax amalthaea), whereas the A2.1b.2 subcluster includes exclusively MN12-MN13 LFAs from Samos (Hipparion dietrichi + Hipparion ex gr. forstenae + Hipparion brachypus + Pachytragus laticeps/crassicornis + Samotherium boissieri/major). This geographical separation is probably strengthened by the isolated placement of the late MN11 assemblages from Samos (Qx and Q6) in to A2.1 subcluster 
with typical faunal association: Samotherium boissieri + Criotherium argalioides + Majoreas woodwardi.

Apart from the poor large mammal assemblages of Ravin of Voulgarakis (RVL, MNQ20), Volos (VLS, MNQ20) and Kaiafas (KAF, MNQ20), the second cluster B is separated in two main subclusters B1 and B2 (Fig. 1). B1 unites Appolakia (APK) and Tourkovounia 3-5 (TKV35) both of rather MN 16 age, whereas $\mathrm{B} 2$ is further divided in two subclusters. B2.1 includes the middle-late Pliocene to earliest Pleistocene (MNQ17-MNQ19) LFAs and it is characterized by the faunal association: Mammuthus meridionalis + Equus stenonis + Eucladoceros ctenoides + Metacervocerus rhenanus + Gazellospira torticornis + Gazella bouvrainae + Leptobos ex. gr. etruscus. B2.2 subcluster unites the early to early-middle Pleistocene LFAs with typical faunal association Canis ex. gr. mosbachensis + Mammuthus meridionalis + Stephanorhinus etruscus + Equus stenonis (last stage) + Hippopotamus antiquus + Praemegaceros pliotarandoides/verticornis + Eobison.

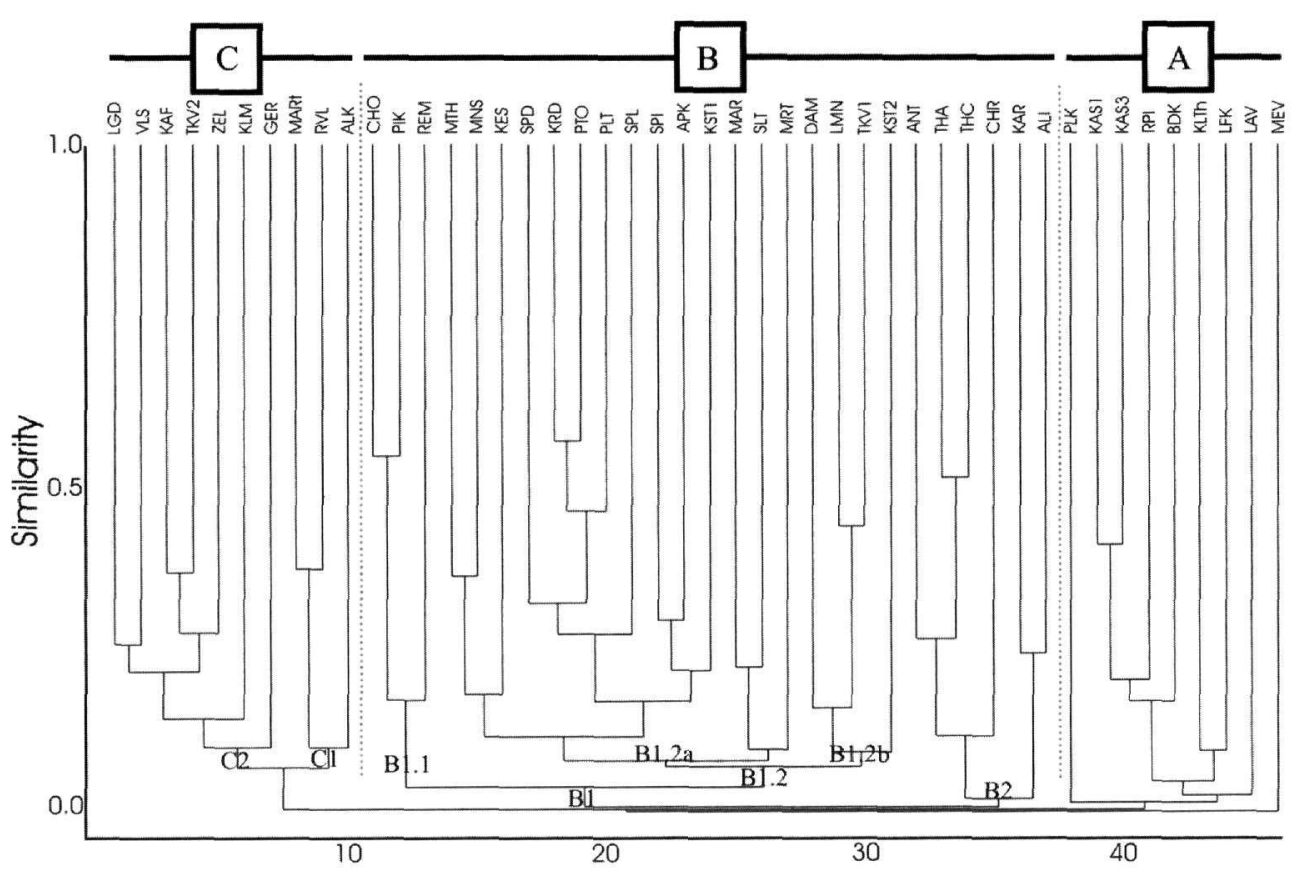

Figure 2 - Q mode dendrogram of 46 Greek small mammal faunas (LFAs). Cophenetic correlation: 0.91

Abbreviations as in Fig. 1 and: Thymiana A (THA); Thymiana C (THC); Chrysavgi (CHR); Karydia I+II (KAR); Plakia (PLK); Kastellios K1 (KAS1); Kastellios K3 (KAS3); Biodrak (BDK); Kalithies (KLTh); Lefkos (LFK); Lava 2 (LAV); Rema Marmara (REM); Ano Metochi 2,3 (MTH); Monasteri (MNS); Spilia 0 (SPD); Kardia (KRD); Ptolemais 1 (PTO); Ptolemais 3 (PLT); Spilia 1 (SPL); Spilia 3,4 (SPI); Kastoria 1 (KST1); Kastoria 2 (KST2); Maritses (MRT); Damartia

(DAM); Limni 6 (LMN); Tourkovounia 1 (TKV1); Tourkovounia 2 (TKV2) Lagada (LGD); Kalymnos (KLM); Marathousa (MARt); Zeli (ZEL)

\subsection{Similarities among small mammal LFAs}

In the species Q-dendrogram of Greek small mammal sites, the LFAs are segregated into three main clusters A, B and C (Fig. 2), whereas the locality of Megalo Emvolo appears as an outlier, evidently because of its extremely poor and specialized small mammal fauna. Unexpectedly, the MN10 LFAs (including the uncertainly dated locality of Kalithies - KLTh) together with some aliens such as Plakia- PLK (MN7-8) and Lava 2 -LAV (MN13) form a separate group (cluster A; Fig. 2) that is distantly related to the main body of Mio-Pliocene faunas (cluster B). Although the 
reasons of this situation are not clear, the absence of MN6-MN9 faunas might once again affect the results. The misplacement of Lava 2 (LAV) within cluster A is due to Leptodontomys catalannicus present in Lava-2 and Biodrak (BDK; MN10) but the species seems to have a wider distribution, being also present in the late MN 13 locality of Maramena (MAR). Excluding problematic LFAs from the analysis the typical faunal association of cluster A appears to be Progonomys cathalai + Byzantinia ex. gr. nikosi + Spermophylinus ex. gr. bredai.

Cluster B is divided in two main subclusters (Fig. 2): B1 unites the MN12 to MN16 LFAs plus Kastoria 2 (MNQ18) and B2 unites the MN 4-5 plus Chrysavgi (CHR, MN7-8). Interestingly the only known MN7-8 Greek faunas of Chrysavgi and Plakia (PLK) do not share any taxon. Nevertheless the affiliation of CHR to the group of MN4/5 (B2) faunas is certainly fictitious, as it is based on the common presence of Schizogalerix sp. and Miomimus sp., both of uncertain specific identification. The typical faunal association of $\mathrm{MN} 4 / 5$ group is Megacricetodon primitivus + Cricetodon aliveriensis-Cricetodon meini \pm Democricetodon, Alloptox, Schizogalerix. The LFAs in B1 subcluster are segregated in two groups: B1.1 gathering MN12 LFAs with a quite characteristic association: Parapodemus gaudryi + Byzantinia pikermiensis + Kowalskia lavocati + Myomimus dehmi + Hystrix primigenia + Occitanomys brailloni + Prolagus michauxi, and B1.2 which is further divided in B1.2a (MN13-MN15/16 LFAs) and B1.2b (MN16 LFAs plus Kastoria 2). Inside B1.2a subcluster the MN13-MN14 LFAs are split in two groups separated by a group of MN14/15-16 LFAs. The situation is rather representative of the homogeneous small mammal fauna that occurs from the end of Miocene to the end of early Pliocene. The typical faunal association of this period includes: Apodemus dominans + Occitanomys adroveri - brailloni + Rhagapodemus hautimangensis + Micromys bendai + Prolagus michauxi + Pseudomeriones, while more wet elements such as Castor fiber characterize the internal group of MN14/15-16 LFAs.

The placement of Kastoria 2 (KST2) inside the B1.2b group of MN 16 LFAs is based on the common presence of Miomimus roachi and Apodemus dominans and the locality is possibly older than it was previously suggested. The faunal association of this time interval is characterized by the association Apodemus dominans + Mimomys hajnackensis + Orientalomys similis + Pliomys graecus + Rhagapodemus athenensis + Dryomimus.

Cluster $\mathrm{C}$ unites the latest Pliocene to early-middle Pleistocene LFAs and although two main groups can be detected ( $\mathrm{C} 1$ and $\mathrm{C} 2$ ) there is no chronological or other meaning in this division. The typical faunal association of this period is compiled by Apodemus mystacinus + Apodemus sylvaticus /flavicolis + Mimomys ex. gr. savini + Cricetulus migratorius + Allophaiomys sp. + Lagurodon arankae.

\section{Discussion and Conclusion}

The comparison of mammalian LFAs from Greece by means of multivariate techniques shows a quite good resolution in the cluster definition of higher hierarchical rank. Some minor discrepancies are mostly due to the fossil record biases, as well as to the insufficient taxonomical interpretations at species level. Figure 3 summarizes the basic structure of both the large and small mammal LFAs clustering, excluding unnecessary outliers. It is evident that there is a good arrangement according to time and that the European Biochronlogical framework is broadly respected. The analyses allow recognizing in both cases a main cluster gap, corresponding to an important reorganization of the paleocommutity. These two basic groups of LFAs represent different "Mammal Ages", characterized by a well identified mammal compilation. Although the large and small mammal LFAs show a similar general clustering pattern in the highest hierarchical rank, the lower hierarchical rank groups show several differences between large and small mammal faunas, raising interesting suggestions.

In both the micro- and macro-mammal cases there is a serious change between the $\mathrm{MN} 4 / 5$ and MN9/10 faunas but the misplacement of the MN7-10 small mammal LFAs is hardly appreciable. 
Anyway, the small mammal community seems to change more progressively; several small mammals (usually identified at genus level such as, Megacricetodon, Myomimus, Prolagus, Pliospalax), that appeared during MN4/5 they are still present in MN13/14 LFAs, though absent from intermediate faunas. Apart from Deinotherium no other large mammal appears to be present in later times.

The clear separation of the middle Miocene large mammal association from the Vallesian one might reflect the emergence of drier and more open environmental conditions in the Eastern Mediterranean area (Koufos, 2006) but the poor representation of MN6-MN8 large mammal LFAs might affect the results. The Turolian geographical separation between the large mammal faunas from continental Greece and the eastern coasts is not observable in the small mammal fauna. This severance should be explained by the presence of a geographic barrier in between the two regions that might prevent extensive large mammal interchanges. The absence of Mesopithecus in the east and the presence of different but relative large taxa or morphotypes of the same species from every quarter support this hypothesis. Geraads et al. (2005) discuss the presence of a humid/forest corridor along the eastern shore of Aegean Sea during Vallesian times, while other authors already suppose the existence of a marine connection between the Aegean Sea and Parathethys in the early Tortonian (Meulekamp and Sissingh 2003). It is quite possible that such kind of barrier or its leftovers was still active in later times (e.g. early-middle Turolian).

LARGE MAMMAL LFAs

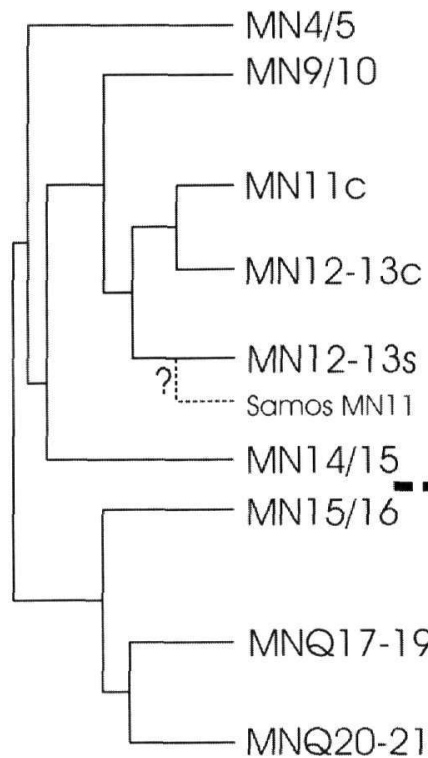

SMALL MAMMAL LFAS

$$
\text { MN7-10 }
$$

$\mathrm{MN} 4 / 5$

MN12

MN13-14

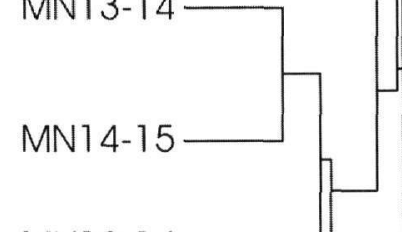

MN13-14

MN16

Figure 3 - Comparison of large and small mammal LFAs clustering

Cluster groups are directly referred to the European Mammal Neogene/Quaternary zones, excluding unnecessary outliers. Dashed line indicates the major break in the two LFAs successions. MN 11 and MN12-13 faunas are marked by a "e" for continental and an "s" for insular

In a general way, the large mammal community seems to respond more immediately to broad climatic trends such as the early Pliocene wetness, the mid-Pliocene desiccation and the early Pleistocene deterioration. On the contrary, both the late Miocene - early-middle Pliocene and the latest Pliocene - early Pleistocene small mammal community appear to be rather homogeneous.

The fundamental reorganizations in the faunal composition do not appear to be synchronous in the two communities. The basic renewal into the large mammal fauna takes place at the end of early Pliocene (end of Ruscinian), time which roughly corresponds to the first Pliocene crisis at 3.2 Ma, when the glaciation process emerges in the Northern Hemisphere (Agusti and Antón 2002). 
Although, the lack of MN17 small mammal LFAs might alter the results, the main change in the small mammal community seems to take place somewhat later, during middle-late Pliocene $(\sim 2.6 \mathrm{Ma})$ as a response to the true establishment of a glacial-interglacial dynamics (Agusti and Antón 2002), which allow the south-eastern part of Europe to enter into a drier phase. On the other hand, the faunal reconstruction of the micromammalian community between middle Turolian and late Turolian/Ruscinian that coincides with the re-establishment of humid conditions in the Balkans, appears slightly later in the large mammal assemblage (at the end of Miocene). The causes of apparent diachrony between small and large mammal faunal renewals are plausibly controlled by several factors and a further analysis is needed. Undersampling and stratigraphic incompatibility between the successions of small and large mammal LFAs seem to play a key role in the present case but biotic reasons such as the different response rate of the two mammal groups in climate changes should also be in consideration.

\section{Acknowledgements}

The first author is grateful to Prof. M.-R. Palombo (Rome) for collaboration and discussions on the faunal similarity multivariate techniques and problems. Thanks are also due to two anonymous reviewers for valuable comments and suggestions.

\section{References}

Agusti, J., and Antón, M., 2002. Mammoths, Sabertooths, and Hominids, Columbia University Press, New York. 313p.

Agusti, J., Cabrera, L., Garces, M., Krijgsman, W., Oms, O., and Pares, J., 2001. A calibrated mammal scale for the Neogene of Western Europe . State of the art, Earth Science Review, $52,247-260$.

Alberdi, M.T., Azanza, B., Cerdeño, E., and Prado, J.L., 1997. Similarity relationship between mammal faunas and biochronology from latest Miocene to Pleistocene in the Western Mediterranean area, Eclogiae Geologica Helvetiae, 90 (1), 115-132.

Azanza, B., Palombo, M. R., and Alberdi, M. T., 2003. Similarity relationaships between large mammal faunas of Spanish and Italian peninsulas from the latest Miocene to the middle Pleistocene, Neues Jahrbuch für Geologie und Paläontologie Abh., 229 (1), 95-127.

Bonis, L. de, and Koufos, G. D., 1999. The Miocene large mammal succession in Greece. In J. Agusti, L. Rook and P. Andrews (eds), The Evolution of Neogene terrestrial ecosystems in Europe. vol. 1. 205-237pp. Cambridge University Press.

Geraads, D, Kaya, T., and Mayda, S., 2005. Late Miocene large mammals from Yulafli, Thrace region, Turkey, and their biogeographic implications, Acta Palaeontologica Polonica, 50 (3), 523-544.

Gliozzi, E., Abbazzi, L., Ambrosetti, P., Argenti, P., Azzaroli, A., Caloi, L., Capasso Barbato, L., Di Stefano, G., Esu, D., Ficcarelli, G., Girotti, O., Kotsakis, T., Masini, F., Mazza, P., Mezzabotta, C., Palombo, M.R., Petronio, C., Rook, L., Sala, B., Sardella, R., Zanalda, E., and Torre, D., 1997. Biochronology of selected Mammals, Molluscs, Ostracods from the Middle Pliocene to the Late Pleistocene in Italy. The state of the art, Rivista Italiana di Paleontologia e Stratigrafia, 103 (3), 369-388.

Guérin, C., 1982. Première biozonation du Pléistocène européen, principal résultat biostratigraphique de l'étude des Rhinocerotidae (Mammalia, Perissodactyla) du Miocène terminal au pléistocène supérieur de l'Europe occidentale. Geobios, 15 (4), 593-598. 
Guérin, C., 1990. Biozones or Mammal Units? Methods and Limits in Biochronology. In E.H. Lindsay, V. Fahlbusch and P. Mein (eds), European Neogene Mammal Chronology, 119130pp. Plenum Press, New York.

Hammer, O., and Harper, D.A.T., 2005. Paleontological Data Analysis, 368pp. Blackwell.

Hammer, O., Harper, D.A.T., and Ryan, P. D., 2001. PAST: Paleontological Statistics Software Package for Education and Data Analysis, Palaeontologia Electronica, 4(1), 9pp. http://palaeo-electronica.org/2001_1/past/issue1_01.htm

Koufos, G.D., 2001. The Villafranchian mammalian faunas and biochronology of Greece, Bollettino della Societa paleontologica Italiana, 40 (2), 217-223.

Koufos, G. D., 2006. The Neogene mammal localities of Greece: faunas, chronology and biostratigraphy, Hellenic Journal of Geosciences, 41 (1), 183-214.

Koufos, G.D., and Kostopoulos, D.S., 1997. Biochronology and succesion of the Plio-Pleistocene macromammalian localities of Greece. In J.-P. Aguilar, S. Legendre and J. Michaux (eds), Actes du Congés BiochroM'97, Mémoires et Travaux de l'Institute de Montpellier 21, 619$634 \mathrm{pp}$, Montpellier.

Lindsay, E.H., and Tedford, R.H., 1990. Development and application of Land Mammal Ages in North America and Europe, a comparison. In E.H. Lindsay, V. Fahlbusch, and P. Mein, (eds), European Neogene Mammal Chronology, 601-624pp. Plenum Press, New York.

Mein, P., 1975. Résultats du groupe de travail des vertébrés: biozonation du Néogène méditerranéen à partir des Mammifères, Report Activity RCMNS working groups, 78-81, Bratislava.

Mein, P., 1990. Updating of MN zones. In E.H. Lindsay, V. Fahlbusch, P. and Mein, (eds) European Neogene Mammal Chronology, 73-90pp. Plenum Press, New York.

Meulekamp, J.E., and Sissingh, W., 2003. Tertiary palaeogeography and tectonostratigraphic evolution of the northern and southern Peri-tethys platforms and the intermediate domains of the African-Eurasian convergent plate boundary, Palaeogeography, Palaeoclimatology, Palaeoecology, 196, 209-228.

Palombo, M.R., and Valli, A.M.F., 2004. Similarities between large mammal faunas of the Italian Peninsula and France from the Pliocene to the middle Pleistocene, Neues Jahrbuch für Geologie und Paläeontologie Abh., 233 (1), 69-102.

Palombo, M.R., and Valli, A.F.M., 2005. Highlighting the Early-Middle Pleistocene transition in Italian and French large mammal faunas: similarities and faunal renewals. In M.J. Head and P.L. Gibbard (eds), Early-Middle Pleistocene Transitions: The Land-Ocean Evidence. Geological Society, London, Special Publications, 247, 263-276pp.

Palombo, M.R., Azanza, B., and Alberdi, M.T., 2003. Italian mammal biochronology from Latest Miocene to Middle Pleistocene: a multivariate approach, Geologica Romana, 36, 335-368.

Palombo, M.R., Valli, A.M.F., Kostopoulos, D.S., Alberdi, M.T., Spassov, N., and Vislobokova, I., 2006. Similarity relationships between the Pliocene to middle Pleistocene large mammal faunas of southern Europe from Spain to the Balkans and the north Pontic region. In R.-D. Kahlke, L.C. Maul and P.P.A. Mazza (eds), "Late Neogene and Quaternary biodiversity and evolution: Regional developments and interregional correlations". Proceedings of the $18^{\text {th }}$ International Senckenberg Conference (VI International Palaeontological Colloquium in Weimar). Courier Forschungsinstitut Senckenberg, 256, 392-347pp.

Shi, G.R., 1993. Multivariate data analysis in palaeoecology and palaeobiogeography -A review, Palaeogeography, Palaeoclimatology, Palaeoecology, 105, 199-234. 